\title{
Genetic parameters of feed intake, production, body weight, body condition score, and selected type traits of Holstein cows in commercial tie-stall barns
}

\author{
J. E. Vallimont, ${ }^{*}$ C. D. Dechow, ${ }^{* 1}$ J. M. Daubert, ${ }^{*}$ M. W. Dekleva, ${ }^{*}$ J. W. Blum,† C. M. Barlieb, ${ }^{*}$ W. Liu, ${ }^{*}$ \\ G. A. Varga, ${ }^{*}$ A. J. Heinrichs, ${ }^{*}$ and C. R. Baumrucker* \\ *Department of Dairy and Animal Science, The Pennsylvania State University, University Park 16802 \\ †Veterinary Physiology, Vetsuisse Faculty, University of Bern, 3012 Bern, Switzerland
}

\begin{abstract}
The objectives of this study were to determine the feasibility of measuring feed intake in commercial tiestall dairies and infer genetic parameters of feed intake, yield, somatic cell score, milk urea nitrogen, body weight (BW), body condition score (BCS), and linear type traits of Holstein cows. Feed intake, BW, and BCS were measured on 970 cows in 11 Pennsylvania tie-stall herds. Historical test-day data from these cows and 739 herdmates who were contemporaries during earlier lactations were also included. Feed intake was measured by researchers once per month over a 24 -h period within $7 \mathrm{~d}$ of 6 consecutive Dairy Herd Information test days. Feed samples from each farm were collected monthly on the same day that feed intake was measured and were used to calculate intakes of dry matter, crude protein, and net energy of lactation. Test-day records were analyzed with multiple-trait animal models, and 305-d fatcorrected milk yield, dry matter intake, crude protein intake, net energy of lactation intake, average BW, and average BCS were derived from the test-day models. The 305-d traits were also analyzed with multiple-trait animal models that included a prediction of 40-wk dry matter intake derived from National Research Council equations. Heritability estimates for 305-d intake of dry matter, crude protein, and net energy of lactation ranged from 0.15 to 0.18 . Genetic correlations of predicted dry matter intake with 305-d dry matter, crude protein, and net energy of lactation intake were 0.84 , 0.90 , and 0.94, respectively. Genetic correlations among the 3 intake traits and fat-corrected milk yield, BW, and stature were moderate to high (0.52 to 0.63). Results indicate that feed intake measured in commercial tie-stalls once per month has sufficient accuracy to enable genetic research. High-producing and larger cows were genetically inclined to have higher feed intake. The genetic correlation between observed and predicted in-
\end{abstract}

Received February 19, 2010.

Accepted June 16, 2010.

${ }^{1}$ Corresponding author: cdd1@psu.edu takes was less than unity, indicating potential variation in feed efficiency.

Key words: feed intake, heritability, body condition score, test day

\section{INTRODUCTION}

The focus of breeding programs worldwide has shifted from one centered mainly on yield to a multifaceted approach that takes into account traits such as reproduction, health, conformation, and longevity, with an overall goal of improving profitability (Miglior et al., 2005). Measurement of feed intake is an important management tool on dairy farms because of its relationship with other traits of economic relevance including production, reproduction, and health; however, feed intake has not been developed into a unique selection trait because of the complications involved in obtaining sufficient observations for genetic analysis. Genetic selection decisions indirectly affect DMI because selections that change milk production and body size of cows also affect DMI (Veerkamp, 1998).

Genetic evaluations of DMI from cows within research herds provide evidence that genetic variation for DMI exists, but data from commercial herds are scarce. Heritability of DMI in dairy cattle has been studied with data from both confinement and pasture-based research herds, and estimates range from 0.10 to 0.46 (van Arendonk et al., 1991; Veerkamp and Brotherstone, 1997; Berry et al., 2007). These values are likely affected by stage of lactation (Koenen and Veerkamp, 1998). Veerkamp and Brotherstone (1997) reported genetic correlations for DMI of $0.62,0.49,0.31$, and 0.23 with fat yield, protein yield, BW, and BCS, respectively. The same study assessed genetic correlations between linear type traits and DMI, and the highest estimates were $-0.55,0.34$, and 0.28 for udder depth, chest width, and body depth, respectively.

The advent of genomic technologies may allow the development of more direct selection for traits such as DMI or feed efficiency (Moore et al., 2009). Although most feed intake data have come from research herds, there are commercial herds (primarily tie-stall herds) 
that feed cows individually and that could provide feed intake measurements. In 2007, it was estimated that lactating cows were housed in tie-stall or stanchion barns on $49.2 \%$ of US dairy farm operations (USDA, 2007). The objectives of this study were 1) to determine the feasibility of estimating DMI in commercial tie-stall dairy herds with sufficient accuracy to facilitate genetic research, 2) to estimate heritability of DM, energy, and $\mathrm{CP}$ intakes, and 3) to assess genetic correlations of intake with yield and other routinely recorded traits.

\section{MATERIALS AND METHODS}

\section{Data}

Feed intake, BW, and BCS were recorded in 11 tiestall herds from the fall of 2008 through the spring of 2009. All herds were initially visited in September to record BCS and heart girth circumference and to determine feeding schedules. All BCS were assigned by a single research technician $(1=$ emaciated and 5 = obese; Wildman et al., 1982). Body weights were estimated from heart girth circumferences according to Heinrichs et al. (1992). Feed intake measurement began in October for 7 herds, and in November for 4 herds that had cows on pasture during October. Feed intake was measured once per month within $7 \mathrm{~d}$ of 6 consecutive DHI tests. Cows were assigned BCS at each visit and heart girth circumference was measured for cows that were 0 to 60 DIM, 130 to 170 DIM, and 280 to 320 DIM. Linear scores for type traits were assigned once in the fall (October through December) and once in the spring (March through May) by a single research technician who received training through a summer classifier internship with the Holstein Association USA Inc. (Brattleboro, VT).

Total mixed rations were sampled monthly on the same day that feed intake was measured, and were delivered to Cumberland Valley Analytical Services, Inc. (Hagerstown, MD) for nutrient analysis. Different types of dry hay (grass first cutting, grass second cutting, alfalfa, timothy, alfalfa old seeding, alfalfa 2008 seeding, alfalfa round bale, alfalfa third cutting, mixed hay, mixed grass hay, and mixed alfalfa hay) were analyzed once for each farm, and top dress grain mixes were analyzed once per farm except for one herd that changed their grain mix during the trial. The top dress mix for this herd was analyzed twice. Feed analysis results were used to determine intakes of dry matter, CP (CPI) and $\mathrm{NE}_{\mathrm{L}}\left(\mathbf{N E}_{\mathrm{L}} \mathbf{I}\right)$.

Our goal was to measure 24 -h feed intake with minimal disruption to each farm's normal feeding routine. On $\mathrm{d} 1$, researchers arrived at the farm for the first morning feeding and remained throughout the day to record details about all of the later daily feedings. Each feeding was completed by the farmer in 45 min or less on most of the farms, and most cows began eating immediately once fed, which prevented individual weighing of feed delivered to each cow. On feed trial days, farmers were instructed to deliver feed among cows as evenly as possible and not to move feed from one cow to another. There were no dividers placed between individual cows to prevent cows pushing feed toward or eating feed from a neighboring cow. The normal routine on these farms involved sweeping feed from cows that had excess after they had an opportunity to eat to cows that had no feed left. On trial days, research technicians used a shovel to move feed from cows with excess to cows lacking feed. Adjustments in intake measurements were made after determining the weight of a standard shovelful of feed for that farm on each trial date. Researchers arrived before the first morning feeding on the second day to weigh feed refusals for each cow individually. It was apparent that the weight of feed refusals was overestimated when water-cups overflowed or a cow lapped water from the cup into her feed causing feed refusals to be wet. The condition of the feed refusals (normal, wet, or very wet) was recorded to account for such instances. It was assumed that an individual cow's feed intake could not be determined precisely under field conditions, but that a cow's general tendency to eat more or less than average would be determined accurately and that measurement error would occur randomly across cows.

A description of each herd's general feeding practices (number of feedings per day, whether the herd fed TMR, how dry hay was fed, and whether the herd used a grain topdress) are reported in Table 1. Ten herds fed TMR; those farms had either a feed cart equipped with a scale or a separate TMR mixer with a scale that unloaded the TMR into the feed cart. The weight of feed in each cart was recorded, and the farmers were instructed to deliver TMR to cows as evenly as possible. Each cow was assumed to receive the same amount of feed from the cart; however, researchers followed the feed cart and randomly weighed the feed in front of individual cows that had not begun eating to make sure that the feed distribution was relatively even. Feed delivery records were adjusted accordingly in instances where there was a tendency for an increasing or decreasing level of feed delivery as the cart progressed along a string of cows. Those cows that clearly received a higher or lower amount of feed (often the first or last cow in a string) also had their feed weighed individually.

In herds that fed dry hay to all cows, equal amounts were given to each cow and the amount delivered to individual cows was weighed randomly. Some herds only fed dry hay to early lactation cows, and the amount of hay was weighed individually in those cases. Herds that 
Table 1. General herd feeding practices

\begin{tabular}{lccll}
\hline Herd & TMR & $\begin{array}{c}\text { TMR } \\
\text { feedings, } n\end{array}$ & Dry hay & $\begin{array}{l}\text { Grain top } \\
\text { dress }\end{array}$ \\
\hline 1 & Yes & 5 & Fed separately from TMR to all cows & No \\
2 & Yes & 4 & None & No \\
3 & Yes & 2 & Fed separately from TMR to fresh cows & Yes/varied \\
4 & Yes & 4 & Fed separately from TMR to all cows & Yes/varied \\
5 & No & & Fed to all cows & Yes/varied \\
6 & Yes & 2 & None & No \\
7 & Yes & 3 & None & No \\
8 & Yes & 2 & Fed as part of TMR to all cows & Yes/varied \\
9 & Yes & 2 & Fed separately from TMR to all cows & Yes/even \\
10 & Yes & 2 & Fed separately from TMR to all cows & No \\
11 & Yes & 2 & Fed separately from TMR to all cows &
\end{tabular}

${ }^{1}$ Varied $=$ cows fed different amounts of topdress depending primarily upon stage of lactation, milk yield, and $\mathrm{BCS}$; even $=$ all cows fed the same amount of topdress.

fed a top-dress grain mix used a feed scoop that delivered a known amount of feed. One herd did not feed TMR; that herd fed corn silage, dry hay from square bales, dry hay from round bales, baleage, high moisture corn, and a grain mix separately. An even amount of hay was delivered to each cow, and hay from cows with a clear deviation from the string was weighed individually. Silage, baleage, and high moisture corn were generally distributed evenly, and cows receiving more or less than surrounding cows had their feed weighed individually.

Test-day milk yield, fat and protein content, SCS, and MUN were retrieved for all cows through September 2009. Additionally, all previous lactation test-day records were obtained for cows in the trial and from herdmates that were not in the herd during the trial, but were contemporaries during earlier lactations. All herds had MUN records during the trial, and 7 herds regularly tested MUN during the year before commencement of this trial. Yield of $4 \% \mathrm{FCM}$ was derived from test-day milk and fat yields (NRC, 2001).

Final data included records from cows born in 2000 or later and from cows in their seventh lactation or less. Records beyond 500 DIM were not included in the final data set. The number of records, cows, and the average of each trait are reported by herd in Table 2 .

\section{Data Analysis}

Data were first analyzed with 3- and 4-trait test-day animal models. For 3 -trait models, milk yield, 1 measure of intake (DMI, CPI or $\mathrm{NE}_{\mathrm{L}} \mathrm{I}$ ), and 1 additional trait were considered, whereas FCM, intake (DMI, $\mathrm{NE}_{\mathrm{L}} \mathrm{I}$, or $\mathrm{CPI}$, BW, and BCS were considered for 4-trait models. Traits were analyzed with the following model in ASREML (Gilmour et al., 2006):

$$
\begin{gathered}
y_{i j k l m n o p}=L_{i j}+A G E_{i k}+M_{i l} \\
+\sum_{m=1}^{x} a_{i m} \times D I M^{m}\left(L G_{n}\right)+H_{i o}+A_{i p}+P_{i p}+A L_{i p}+\varepsilon_{i j k l m n o p}
\end{gathered}
$$

where $y$ is the test-day record for trait $i ; L$ is the fixed effect of lactation $j$ for trait $i ; A G E$ is the fixed effect of age-at-calving group $k$ (34 levels with 2 -mo classes beginning with class $\leq 20$ mo and ending with class $\geq 86$ mo) for trait $i$; $M$ is the fixed effect of months carried calf $l$ for trait $i ; a$ is the fixed regression coefficient on DIM $(x=7$ for intake, BW, and BCS at $P<0.05$; and $x=10$ for all other traits at $P<0.05)$ nested within lactation-group $(L G) n(1,2$, and $\geq 3$ lactation) for trait $i ; H$ is the fixed effect of herd test-date $o$ for trait $i$; $A$ is the random additive genetic effect of animal $p$ for trait $i ; P$ is the random across-lactation permanent environmental effect of cow $p$ for trait $i$; $A L$ is the random lactation-specific effect of cow $p$ (within lactation environmental effect) for trait $i$; and $\varepsilon$ is random error. Cows with wet feed refusals had underestimated feed intakes because the additional water added weight to their refusals and intake was total feed delivered minus the weight of refusals; therefore, additional polynomial effects for DIM were nested within feed refusal condition $(0=$ normal, $1=$ wet, $2=$ very wet $)$ for DMI, $\mathrm{CPI}$, and $\mathrm{NE}_{\mathrm{L}} \mathrm{I}$. Eight residual variance structures corresponded to DIM -9 to 84,85 to 182,183 to 280 , and 281 to 500 for lactation 1 and for lactation $\geq 2$. Five dry cows that were in their stalls before calving and had a BCS up to $9 \mathrm{~d}$ before calving were included in the analysis; however, no intake data from those dry cows was included. Attempts to fit random regression effects 
for the additive genetic component of intake were not successful (failed to converge to positive-definite solutions) so random regression models were not considered further. The pedigree file contained 4,432 animals and ancestry was traced back through as many as 10 generations. All herds used AI bulls and there were pedigree connections among the herds.

The solutions from model [1] were used to derive standardized daily phenotypic FCM, DMI, CPI, $\mathrm{NE}_{\mathrm{L}} \mathrm{I}, \mathrm{BW}$, and BCS. Best linear unbiased estimators (BLUE) corresponding to the cow's lactation number $\left(L_{i j}\right)$, the most frequent age class for each lactation $\left(A G E_{i k}=\right.$ $24 \mathrm{mo}$ for lactation $1,38 \mathrm{mo}$ for lactation $2,50 \mathrm{mo}$ for lactation 3, 64 mo for lactation 4, 82 mo for lactation 5, 86 mo for lactations 6 and 7), month carried calf assuming the cow was open $150 \mathrm{~d}\left(M_{i l}\right)$, days in milk $\left(a_{i m}\right)$, and January 2009 herd test-date $\left(H_{i o}\right)$ were summed. The BLUP for additive genetic effects $\left(A_{i p}\right)$, permanent environmental effects $\left(P_{i p}\right)$, and lactationspecific cow effects $\left(A L_{i p}\right)$ were added to the BLUE to generate the daily phenotypic standardized records. Records for FCM and BW were also used to derive predicted DMI (PDMI) for the first 40 wk of lactation with the following formula (NRC, 2001):

$$
\begin{gathered}
\text { PDMI }(\mathrm{kg} / \mathrm{d})=[(0.372 \times \mathrm{FCM}) \\
\left.+\left(0.0968 \times \mathrm{BW}^{0.75}\right)\right] \times\left[1-\mathrm{e}^{(-0.192) \times(\mathrm{WOL}+3.67)}\right],
\end{gathered}
$$

where WOL is week of lactation.

Lactation totals or averages were generated for each trait. Daily FCM, DMI, CPI, and $\mathrm{NE}_{\mathrm{L}} \mathrm{I}$ from DIM 5 to 305 were summed to generate standardized 305-d records, daily PDMI for first $40 \mathrm{WOL}$ were summed, and the average of daily BW and BCS from 5 to 305 DIM were determined. The lactation totals (or averages) were then analyzed with the following 5 -trait animal models that included FCM, BW, BCS, PDMI, and DMI, CPI, or $\mathrm{NE}_{\mathrm{L}} \mathrm{I}$ in ASREML (Gilmour et al., 2006):

$$
y_{i j k l}=L_{i j}+H C C_{i k}+A_{i l}+P_{i l}+\varepsilon_{i j k l},
$$

where $y$ is the lactation record for trait $i$; $L$ is the fixed effect of lactation $j$ for trait $i$; $H C C$ is the fixed effect of herd-calving-cluster $k$ for trait $i$; $A$ is the random additive genetic effect of animal $l$ for trait $i$; $P$ is the random permanent environmental effect across lactations for cow $l$ for trait $i$; and $\varepsilon$ is random error. The herds in the trial were relatively small and many herd-year-seasons had few calvings, so clustering was used to derive contemporary groups. The FASTCLUS procedure of SAS (version 9.1.2, SAS Institute Inc., Cary, NC) was used to determine clusters and they were required to be at least $60 \mathrm{~d}$ apart with a minimum of 10 calvings per cluster. The number of clusters per herd ranged from 4 to 18 . There were 140 herd-calving-clusters, ranging in size from 11 to 58 cows with an average of 25.9 cows.

\section{RESULTS AND DISCUSSION}

Final data included test-day and feed intake information from 970 cows and historical test-day information from an additional 739 cows, resulting in full data analysis of records from 1,709 cows. Test-day, feed intake, and lactation total results are presented in Table 2.

\section{Intake}

The average DMI across herds was $22.2 \mathrm{~kg}$ and the values ranged from 19.8 to $26.7 \mathrm{~kg}$ for intakes calculated with refusals that were not observed to have extra moisture from overflowing water-cups. The DMI results are comparable with other studies that measured DMI for individual cows (Vallimont et al., 2001; Ordway et al., 2009). The average standardized daily DMI for lactations 1, 2, and $\geq 3$ are illustrated in Figure 1a. The curves depict 2 anticipated trends: (1) increasing intake in early lactation followed by a plateau, and (2) firstlactation animals eating less than those in later lactations. Both observations suggest that the on-farm data collection method was successful in capturing variation in feed intake among cows. The curves are not smooth at the end of lactation because of the effect of months carried calf. Across all herds, intake records for the first 305 DIM were relatively evenly distributed by month of lactation, ranging from 8 to $11 \%$. Month 10 had the lowest percentage of intake records (8\%) and mo 2, 3, 4 , and 5 had the highest portion of records ( $11 \%$ of records from each of those months). The percentage of refusals within herds that were wet or very wet ranged from 6.4 to $43.8 \%$ with an average of $22.4 \%$ across all herds. The effect of overflowing water-cups is clearly an additional source of variation that must be considered in commercial tie-stall herds. Although research technicians in this study recorded the general condition of feed refusals, the observations (normal, wet, very wet) were subjective and added inaccuracy to the data.

Predicted DMI was limited to the first $40 \mathrm{wk}$ of lactation because the NRC (2001) equation was derived primarily from this period. Ellis et al. (2006) compared actual DMI data to predicted DMI using the NRC (2001) equation and found that the NRC equation tends to underestimate intake; however, it had the least amount of error among the 3 methods tested, which also included those developed by the Agricultural Research Council (ARC, 1980) and the Cornell Net Carbohydrate and Protein System (Fox et al., 2004). Predicted DMI for 

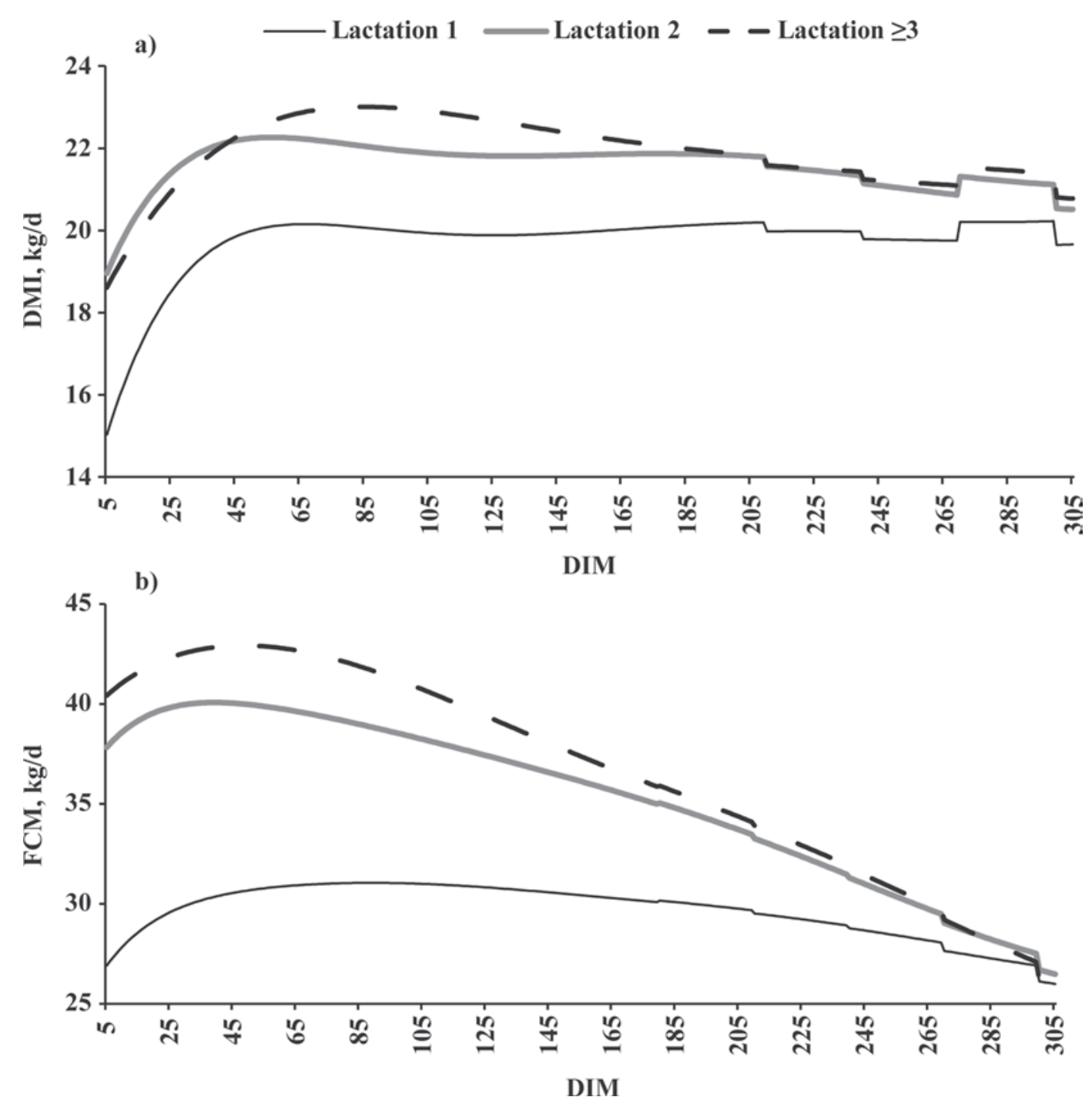

Figure 1. Average standardized daily DMI (a) and FCM yield (b) for lactations 1,2 , and $\geq 3$.

the current study was lower than 305-d DMI for many of the herds, in part because PDMI was calculated only through $280 \mathrm{~d}$. Crude protein intake averaged $3.64 \mathrm{~kg} / \mathrm{d}$ and ranged from 3.09 to $4.39 \mathrm{~kg} / \mathrm{d}$. Net energy of lactation intake averaged $36.38 \mathrm{Mcal} / \mathrm{d}$ and ranged from 32.87 to $44.65 \mathrm{Mcal} / \mathrm{d}$.

\section{$B W$ and $B C S$}

A total of 2,195 BW estimates (derived from heart girth measurements) were taken during the trial and averaged $678.7 \mathrm{~kg}$, whereas average standardized 305-d BW was $655.6 \mathrm{~kg}$. Body condition score averaged 3.18 across 4,998 BCS measurements, but there was a wide range of BCS among herds (2.85 to 3.54). On average, cows reached nadir BW 20 to $43 \mathrm{~d}$ before reaching their lowest BCS, depending on parity (Figure 2). Trends for both BW and BCS followed expected patterns with rapid decreases in early lactation followed by gradual increases throughout the remainder of the lactation.

\section{Milk Production Variables}

Test-day milk yield averaged $34.52 \mathrm{~kg}$ across all herds and ranged from 31.13 to $40.64 \mathrm{~kg}$. Milk fat and milk protein content averaged 3.75 and $3.07 \%$, respectively. The average standardized FCM yield was $9,559.5 \mathrm{~kg}$. The highest yielding herd had 11,917.9 kg of FCM, whereas the lowest yielding herd had 8,051.6 kg of FCM. The average standardized daily FCM yields for lactations 1 , 2 , and $\geq 3$ are illustrated in Figure 1b. Curves of both DMI and FCM were persistent and without a well- 

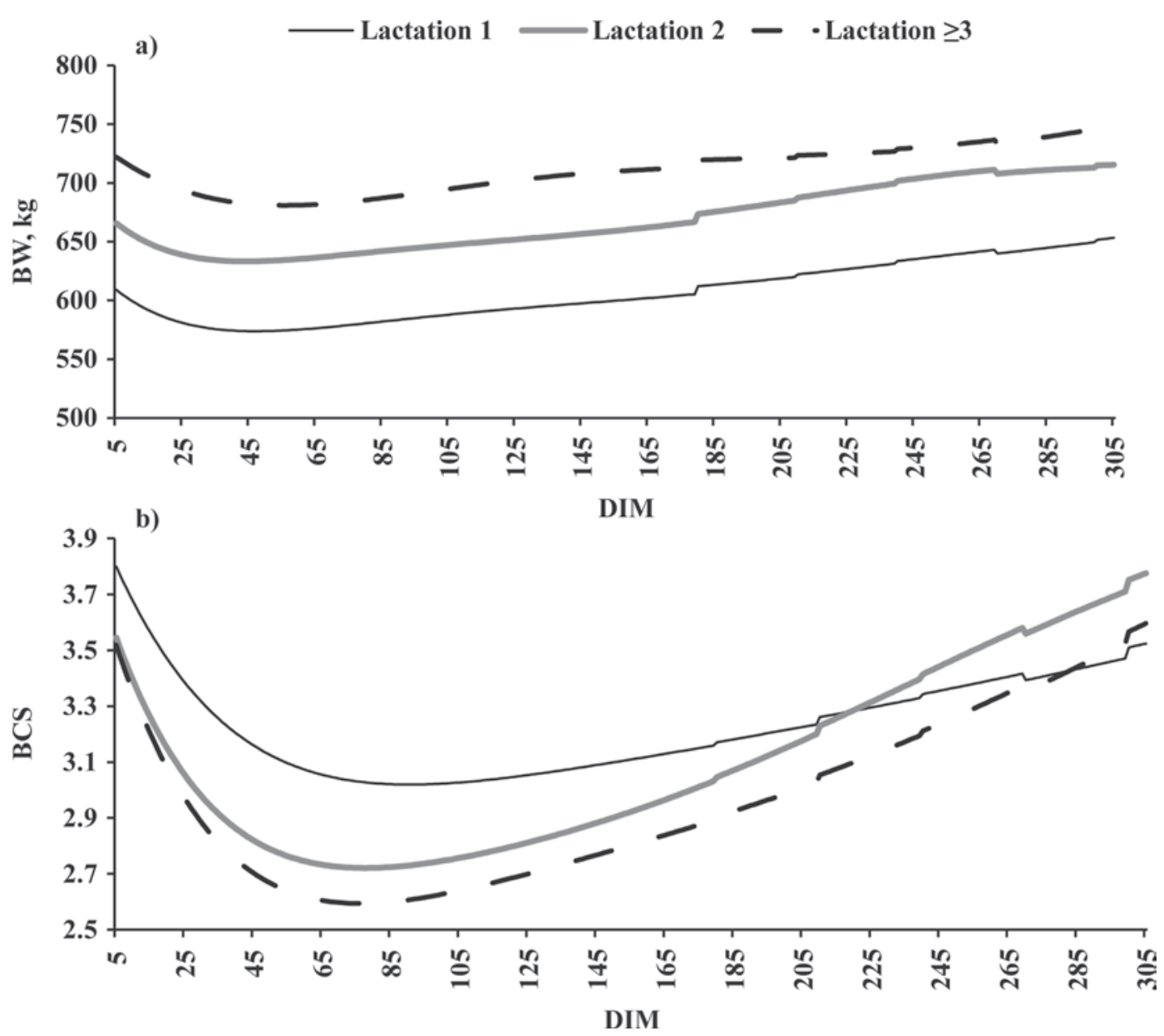

Figure 2. Average standardized daily BW (a) and BCS (b) for lactations 1,2 , and $\geq 3$.

defined peak for first-lactation cows. Peak FCM was achieved at 88 DIM and DMI increased until 67 DIM and remained relatively level through the remainder of lactation (within $0.58 \mathrm{~kg}$ ). Peak FCM was achieved 17 and 36 DIM earlier than peak DMI for lactations 2 and $\geq 3$, respectively. Milk urea nitrogen values were typical (Mitchell et al., 2005) and ranged from 8.73 to 14.89 $\mathrm{mg} / \mathrm{dL}$, with an average of $12.30 \mathrm{mg} / \mathrm{dL}$.

The product-moment correlation between FCM and DMI for each herd is reported in Table 2. The lowest estimate corresponded to the largest herd (herd 6), and could have indicated that feed intake measurements were least accurate for this herd. Cows were fed rapidly in herd 6, which may have resulted in less-even feed distribution and fewer opportunities to weigh feed delivered to individual cows. Herd 11 also had a low correlation between FCM and DMI (0.36). This herd had the lowest milk yield, but had relatively high intake of a low CP diet (14.4\%), which may have affected the relationship between intake and yield. The 5 herds that used a grain topdress were also the 5 herds that had the highest correlation between DMI and FCM. This may indicate that they were feeding more closely to individual cow needs or that intake measurements were more accurate for these herds. In addition, the only herd that used a component feeding system (herd 5) had the highest correlation between DMI and FCM (0.80). This could indicate that all feed components were fed more closely to production levels in herd 5 . It is also possible that feed delivery measurements for this herd were more accurate than for other herds.

\section{Genetic Correlations and Heritability}

Results from test-day and 305-d genetic analyses are presented in Tables 3 and 4, respectively. Standard errors for the test-day genetic correlations are much higher than those for the whole-lactation analysis. Test-day genetic correlations for milk, fat, and protein yields were similar across all measures of intake (DMI, $\mathrm{CPI}$, and $\mathrm{NE}_{\mathrm{L}} \mathrm{I}$ ) with values ranging from 0.51 to 0.64 ; however, these estimates were not significantly different 
Table 3. Estimates of genetic correlations $( \pm \mathrm{SE})$ among intakes of dry matter (DMI), crude protein (CPI), and net energy of lactation $\left(\mathrm{NE}_{\mathrm{L}} \mathrm{I}\right)$ with test-day records, $\mathrm{BW}$, and $\mathrm{BCS}$

\begin{tabular}{lrrr}
\hline Trait & \multicolumn{1}{c}{ DMI } & \multicolumn{1}{c}{ CPI } & \multicolumn{1}{c}{$\mathrm{NE}_{\mathrm{L}} \mathrm{I}$} \\
\hline Milk yield & $0.51 \pm 0.32$ & $0.58 \pm 0.40$ & $0.53 \pm 0.34$ \\
Fat yield & $0.53 \pm 0.34$ & $0.55 \pm 0.39$ & $0.52 \pm 0.34$ \\
Protein yield & $0.53 \pm 0.30$ & $0.64 \pm 0.39$ & $0.53 \pm 0.33$ \\
FCM & $0.55 \pm 0.37$ & $0.55 \pm 0.40$ & $0.55 \pm 0.36$ \\
BW & $0.52 \pm 0.35$ & $0.60 \pm 0.40$ & $0.38 \pm 0.45$ \\
BCS & $0.37 \pm 0.46$ & $0.46 \pm 0.50$ & $-0.14 \pm 0.34$ \\
SCS & $-0.15 \pm 0.28$ & $-0.19 \pm 0.38$ & $0.40 \pm 0.32$ \\
MUN & $0.44 \pm 0.29$ & $0.44 \pm 0.39$ & \\
\hline
\end{tabular}

from zero because of large standard errors. Nevertheless, Veerkamp and Brotherstone (1997) and van Arendonk et al. (1991) reported similar genetic correlations between milk yield and DMI. Veerkamp and Brotherstone (1997) reported a stronger genetic correlation between fat yield and DMI (0.76). Fat-corrected milk yield had a correlation of 0.55 with all 3 intake measures for testday data. Genetic correlations between 305-d standardized FCM and intake were similar, ranging from 0.52 (DMI) to $0.61\left(\mathrm{NE}_{\mathrm{L}} \mathrm{I}\right)$ with standard errors of 0.17 . Phenotypic correlations between 305-d standardized FCM and intake ranged from 0.35 to 0.38 (Table 4). Genetic correlations for $\mathrm{BW}$ and intake traits were similar for both test-day and 305-d analyses, and estimates ranged from 0.52 to 0.60 . Genetic correlations between BW and $\mathrm{DMI}$ and $\mathrm{NE}_{\mathrm{L}} \mathrm{I}$ were comparable to those of van Arendonk et al. (1991). The genetic correlation between DMI and BW reported by Veerkamp and Brotherstone (1997) was roughly half of the value from the current study. However, that study was limited to wk 1 through 25 of lactation, whereas we included measurements from all stages of lactation. Prior studies (Koenen and Veerkamp, 1998; Toshniwal et al., 2008) have demonstrated that genetic parameters related to BW vary with stage of lactation, so the differences in time spans of the 2 trials may explain the higher genetic correlation between DMI and BW observed in the current study. The phenotypic correlation for $\mathrm{BW}$ and $\mathrm{NE}_{\mathrm{L}} \mathrm{I}$ in the 305-d analysis was 0.30, whereas DMI and CPI had lower phenotypic correlations with BW. The genetic correlation between 305-d standardized BW and FCM was -0.29 . The genetic correlation between BCS and test-day CPI (0.46) was slightly higher than that for BCS and DMI and $\mathrm{NE}_{\mathrm{L}} \mathrm{I}$ (0.37 and 0.38, respectively), but all had high standard errors. Standardized 305-d BCS was likewise positively correlated genetically $(0.17$ to 0.33 ) with intakes of dry matter, energy, and protein. The estimates were relatively small and had large standard errors, but did contrast with the estimate obtained between PDMI and BCS (-0.03). This could indicate that cows with higher DMI than predicted tend to be those with higher BCS. Veerkamp and Brotherstone (1997) reported no genetic correlation between DMI and BCS, however. Phenotypic correlations between BCS and the intake traits were all small and negative. Test-day genetic correlations between SCS and feed intake were slightly negative, whereas estimates between MUN and feed intake were moderately positive, but had large standard errors (Table 3).

Heritability estimates for standardized 305-d intake were $0.18,0.15$, and 0.18 for DMI, CPI, and $\mathrm{NE}_{\mathrm{L}} \mathrm{I}$, respectively, and genetic correlations among these traits were all near unity (Table 4). Koenen and Veerkamp (1998) reported heritability for DMI ranging from 0.18 to 0.37 , depending on stage of lactation. Heritability of DMI from the current study is lower than values reported by both van Arendonk et al. (1991), in a study with lactating heifers, and Veerkamp and Brotherstone (1997), whose study was restricted to the first 26 wk of lactation. Heritability of energy intake was estimated

Table 4. Estimates of heritability $( \pm \mathrm{SE}$, diagonal, bold $)$ and genetic $( \pm \mathrm{SE}$, above diagonal $)$ and phenotypic $( \pm \mathrm{SE}$, below diagonal) correlations among predicted DMI (PDMI), FCM, BW, BCS, and intakes of dry matter (DMI), crude protein (CPI), and net energy of lactation (NE $\mathrm{L}$ ) from 305-d data

\begin{tabular}{lccccccc}
\hline Item & DMI & CPI & NE $E_{\mathrm{L}}$ & FCM & BW & BCS \\
\hline DMI & $\mathbf{0 . 1 8} \pm \mathbf{0 . 0 6}$ & $0.99 \pm 0.00$ & $0.99 \pm 0.00$ & $0.52 \pm 0.17$ & $0.54 \pm 0.16$ & $0.29 \pm 0.24$ & $0.84 \pm 0.14$ \\
CPI & $0.99 \pm 0.00$ & $\mathbf{0 . 1 5} \pm \mathbf{0 . 0 6}$ & $0.99 \pm 0.00$ & $0.54 \pm 0.17$ & $0.60 \pm 0.16$ & $0.33 \pm 0.25$ & $0.90 \pm 0.14$ \\
NE & $0.98 \pm 0.00$ & $0.98 \pm 0.00$ & $\mathbf{0 . 1 8} \pm \mathbf{0 . 0 7}$ & $0.61 \pm 0.17$ & $0.56 \pm 0.16$ & $0.17 \pm 0.25$ & $0.94 \pm 0.15$ \\
FCM & $0.37 \pm 0.03$ & $0.38 \pm 0.03$ & $0.35 \pm 0.03$ & $\mathbf{0 . 2 3} \pm \mathbf{0 . 0 4}$ & $-0.29 \pm 0.13$ & $-0.33 \pm 0.16$ & $0.81 \pm 0.05$ \\
BW & $0.19 \pm 0.06$ & $0.12 \pm 0.06$ & $0.30 \pm 0.07$ & $-0.18 \pm 0.05$ & $\mathbf{0 . 6 0} \pm \mathbf{0 . 0 8}$ & $0.50 \pm 0.12$ & $0.32 \pm 0.12$ \\
BCS & $-0.13 \pm 0.03$ & $-0.14 \pm 0.03$ & $-0.13 \pm 0.03$ & $-0.36 \pm 0.03$ & $0.48 \pm 0.03$ & $\mathbf{0 . 2 6} \pm \mathbf{0 . 0 8}$ & $-0.03 \pm 0.19$ \\
PDMI & $0.43 \pm 0.03$ & $0.43 \pm 0.02$ & $0.41 \pm 0.03$ & $0.93 \pm 0.004$ & $0.28 \pm 0.03$ & $-0.17 \pm 0.03$ & $\mathbf{0 . 2 2} \pm \mathbf{0 . 0 5}$ \\
\hline
\end{tabular}


Table 5. Estimates of genetic and phenotypic correlations $( \pm \mathrm{SE})$ among linear body type traits and DMI, crude protein intake (CPI), net energy of lactation intake $\left(\mathrm{NE}_{\mathrm{L}} \mathrm{I}\right), \mathrm{FCM}, \mathrm{BW}$, and $\mathrm{BCS}$

\begin{tabular}{|c|c|c|c|c|c|c|}
\hline \multirow[b]{2}{*}{ Trait } & DMI & CPI & $\mathrm{NE}_{\mathrm{L}} \mathrm{I}$ & $\mathrm{FCM}$ & BW & $\mathrm{BCS}$ \\
\hline & \multicolumn{6}{|c|}{ Genetic correlations } \\
\hline Stature & $0.55 \pm 0.28$ & $0.63 \pm 0.28$ & $0.58 \pm 0.27$ & $0.25 \pm 0.21$ & $0.94 \pm 0.13$ & $-0.13 \pm 0.25$ \\
\hline Strength & $0.03 \pm 0.33$ & $-0.17 \pm 0.35$ & $-0.18 \pm 0.33$ & $-0.18 \pm 0.24$ & $0.84 \pm 0.15$ & $0.46 \pm 0.23$ \\
\hline Body depth & $-0.03 \pm 0.27$ & $-0.06 \pm 0.29$ & $-0.06 \pm 0.28$ & $0.06 \pm 0.22$ & $0.57 \pm 0.15$ & $-0.14 \pm 0.24$ \\
\hline Rump width & $0.18 \pm 0.23$ & $0.19 \pm 0.24$ & $0.19 \pm 0.23$ & $-0.20 \pm 0.17$ & $0.25 \pm 0.15$ & $0.15 \pm 0.20$ \\
\hline \multirow[t]{2}{*}{ Dairy form } & $0.01 \pm 0.30$ & $0.28 \pm 0.31$ & $0.31 \pm 0.29$ & $0.14 \pm 0.21$ & $0.02 \pm 0.20$ & $-0.87 \pm 0.12$ \\
\hline & \multicolumn{6}{|c|}{ Phenotypic correlations } \\
\hline Stature & $0.12 \pm 0.03$ & $0.11 \pm 0.03$ & $0.11 \pm 0.03$ & $0.02 \pm 0.03$ & $0.38 \pm 0.03$ & $0.08 \pm 0.03$ \\
\hline Strength & $0.01 \pm 0.03$ & $0.04 \pm 0.03$ & $0.04 \pm 0.03$ & $-0.05 \pm 0.03$ & $0.42 \pm 0.03$ & $0.37 \pm 0.03$ \\
\hline Body depth & $0.10 \pm 0.03$ & $0.12 \pm 0.03$ & $0.13 \pm 0.03$ & $0.11 \pm 0.03$ & $0.32 \pm 0.03$ & $0.02 \pm 0.03$ \\
\hline Rump width & $0.07 \pm 0.03$ & $0.09 \pm 0.03$ & $0.03 \pm 0.03$ & $0.04 \pm 0.03$ & $0.23 \pm 0.03$ & $0.06 \pm 0.03$ \\
\hline Dairy form & $0.17 \pm 0.03$ & $0.14 \pm 0.03$ & $0.14 \pm 0.03$ & $0.28 \pm 0.03$ & $-0.10 \pm 0.03$ & $-0.46 \pm 0.03$ \\
\hline
\end{tabular}

to be 0.31 by van Arendonk et al. (1991), which is also higher than results from this study. Lower heritability for feed intake in the current study may reflect some inaccuracies that resulted from measuring feed intake in a commercial tie-stall setting.

Predicted DMI had a moderate heritability of 0.22 (Table 4). Genetic correlations between PDMI and intake traits were $0.84,0.90$, and 0.94 for DMI, CPI, and $\mathrm{NE}_{\mathrm{L}} \mathrm{I}$, respectively. The high genetic correlations suggest that the majority of DMI differences among cows can be explained by differences in FCM and BW, and that measures of DMI were recorded accurately.

Genetic and phenotypic correlations among 5 linear body type traits and intake, FCM, BW, and BCS are given in Table 5. Genetic correlations were moderate to high between intake and stature, and very strong between stature and BW. Body depth was not correlated with intake, and that result is in contrast to Veerkamp and Brotherstone (1997), who reported a genetic correlation of 0.34 between body depth and DMI. Dairy form was strongly and negatively correlated with BCS, which is in agreement with Dechow et al. (2003). Phenotypic correlations between BW and stature, strength, body depth, and rump width were moderate to low, and BCS had moderate phenotypic correlations with strength and dairy form. Heritability estimates for the linear type traits (not shown) ranged from $0.12 \pm$ 0.06 (strength) to $0.31 \pm 0.08$ (rump width) and were generally less than previous estimates (Short and Lawlor, 1992), which could be due to the relatively small sample size.

\section{CONCLUSIONS}

Genetic analysis of feed intake has historically involved the use of records from research herds. Results from this work were generally supported by previous studies, in spite of complications such as wet feed refusals, an inability to individually weigh the feed delivered to each cow, and a lack of feed dividers between cows. Genetic analyses support that variation exists among cows for feed intake and that selection for higher yield and larger body size are associated with a correlated response in feed intake. Genetic correlations between predicted intake and measured $\mathrm{DMI}, \mathrm{CPI}$, and $\mathrm{NE}_{\mathrm{L}} \mathrm{I}$ were high. Further research will explore variation among cows for productive efficiency. Genetic analysis of feed intake data using measures of this trait collected from commercial tie-stall herds is possible.

\section{ACKNOWLEDGMENTS}

This research was supported by CSREES (200834437-19335). The authors gratefully acknowledge the generosity of the 11 farmers who participated in the trial. The linear scoring by Turner Swartz (research associate, Penn State University, State College, PA) is also appreciated.

\section{REFERENCES}

Agricultural Research Council. 1980. The Nutrient Requirements of Ruminant Livestock - Technical Review by an Agricultural Research Council Working Party. Commonwealth Agricultural Bureaux, Slough, UK.

Berry, D. P., B. Horan, M. O'Donovan, F. Buckley, E. Kennedy, M. McEvoy, and P. Dillon. 2007. Genetics of grass dry matter intake, energy balance, and digestibility in grazing Irish dairy cows. J. Dairy Sci. 90:4835-4845.

Dechow, C. D., G. W. Rogers, L. Klei, and T. J. Lawlor. 2003. Heritabilities and correlations among body condition score, dairy form and selected linear type traits. J. Dairy Sci. 86:2236-2242.

Ellis, J. L., F. Qiao, and J. P. Cant. 2006. Prediction of dry matter intake throughout lactation in a dynamic model of dairy cow performance. J. Dairy Sci. 89:1558-1570.

Fox, D. G., T. P. Tylutki, L. O. Tedeschi, M. E. Van Amburgh, L. E. Chase, A. N. Pell, T. R. Overton, and J. B. Russell. 2004. The Net Carbohydrate and Protein System for evaluating herd nutrition and nutrient excretion. Anim. Feed Sci. Technol. 112:29-78. 
Gilmour, A. R., B. J. Gogel, B. R. Cullis, S. J. Welham, and R. Thompson. 2006. ASREML User Guide. Release 2.0. VSN International Ltd., Hemel Hempstead, UK.

Heinrichs, A. J., G. W. Rogers, and J. B. Cooper. 1992. Predicting body weight and wither height in Holstein heifers using body measurements. J. Dairy Sci. 75:3576-3581.

Koenen, E. P. C., and R. F. Veerkamp. 1998. Genetic covariance functions for live weight, condition score, and dry matter intake measured at different lactation stages of Holstein Friesian heifers. Livest. Prod. Sci. 57:67-77.

Miglior, F. B. L. Muir, and B. J. Van Doormaal. 2005. Selection indices in Holstein cattle of various countries. J. Dairy Sci. 88:12551263.

Mitchell, R. G., G. W. Rogers, C. D. Dechow, J. E. Vallimont, J. B. Cooper, U. Sander-Nielsen, and J. S. Clay. 2005. Milk urea nitrogen concentration: Heritability and genetic correlations with reproductive performance and disease. J. Dairy Sci. 88:4434-4440.

Moore, S. S., F. D. Mujibi, and E. L. Sherman. 2009. Molecular basis for residual feed intake in beef cattle. J. Anim. Sci. 87(E Suppl.):E41-E47.

NRC. 2001. Nutrient Requirements of Dairy Cattle. Natl. Acad. Press, Washington, DC.

Ordway, R. S., S. E. Boucher, N. L. Whitehouse, C. G. Schwab, and B. K. Sloan. 2009. Effects of providing two forms of supplemental methionine to periparturient Holstein dairy cows on feed intake and lactational performance. J. Dairy Sci. 92:5154-5166.

Short, T. H., and T. J. Lawlor. 1992. Genetic parameters of conformation traits, milk yield, and herd life in Holsteins. J. Dairy Sci. $75: 1987-1998$
Toshniwal, J. K., C. D. Dechow, B. G. Cassell, J. A. D. R. N. Appuhamy, and G. A. Varga. 2008. Heritability of electronically recorded daily body weight and correlations with yield, dry matter intake, and body condition score. J. Dairy Sci. 91:3201-3210.

USDA. 2007. Dairy 2007, Part I: Reference of Dairy Cattle Health and Management Practices in the United States, 2007. N480.1007. USDA-APHIS-VS, CEAH, Fort Collins, CO.

Vallimont, J. E., G. A. Varga, A. Arieli, T. W. Cassidy, and K. A. Cummins. 2001. Effects of prepartum somatotropin and monensin on metabolism and production of periparturient Holstein dairy cows. J. Dairy Sci. 84:2607-2621.

van Arendonk, J. A. M., G. J. Nieuwhof, H. Vos, and S. Korver. 1991. Genetic aspects of feed intake and efficiency in lactating dairy heifers. Livest. Prod. Sci. 29:263-275.

Veerkamp, R. F. 1998. Selection for economic efficiency of dairy cattle using information on live weight and feed intake: A review. J. Dairy Sci. 81:1109-1119.

Veerkamp, R. F., and S. Brotherstone. 1997. Genetic correlations between linear type traits, food intake, live weight and condition score in Holstein Friesian dairy cattle. Anim. Sci. 64:385-392.

Wildman, E. E., G. M. Jones, P. E. Wagner, R. L. Bowman, H. F. Troutt, and T. N. Sesch. 1982. A dairy cow body condition scoring system and its relationship to selected production characteristics. J. Dairy Sci. 65:495-501. 